23. Logistic_operation_efficiency.xls [Electronic resource].- Available at: \www/URL: https://www.dropbox.com/s/5b7xv4z2xcv4uta/ Logistic_operation_efficiency.xls?dl=0

\section{РАЗРАБОТКА МЕТОДА ФОРМИРОВАНИЯ СИСТЕМНО ОБОСНОВАННОГО УРОВНЯ ЗАПАСОВ ЛОГИСТИЧЕСКИХ ОПЕРАЦИЙ}

Производственная или торговая деятельность всегда связана с необходимостью исследования и формирования параметров логистических операций. Несмотря на продолжительную историю и большое количество проведенных исследований в настоящее время отсутствуют системно обоснованные методы определения оптимальних параметров логистических операций.
Предлагаемый поход обеспечивает возможность создания модели логистической операции и определения системно обоснованного уровня страховых запасов.

Ключевые слова: логистическая операция, модель логистической операции, страховой запас логистической операции.

Lutsenko Igor, Doctor of Technical Sciences, Professor, Department of Information and Control Systems, Kremenchuk Mykhailo Ostrohradskyi National University, Ukraine, e-mail: delo-do@i.ua, ORCID: http://orcid.org/0000-0002-1959-4684

Fomovskaya Elena, PhD, Associate Professor, Head of the Department of Electronic Devices, Kremenchuk Mykhailo Ostrohradsky National University, Ukraine, e-mail: 2fill.fo@gmail.com, ORCID http://orcid.org/0000-0002-8065-5079

\title{
Dligach $\boldsymbol{A}$.
}

\section{DEVELOPMENT OF MARKETING STRATEGIES IN SYSTEM-REFLEXIVE MARKETING}

Запропоновані інтегрована система системно-рефлексивного маркетингу, що базується на програмній формі управління, та трициклічна модель формування стратегії, як сукупність методів, форм та інструментів узгодження інтересів стейкхолдерів на трьох рівнях: опредмечення інтересу управителя по відношенню до об’єкта управління; узгодження інтересів внутрішніх стейкхолдерів; формування стратегї в процесі узгодження інтересів зовнішніх стейкхолдерів. Застосування системно-рефлексивного маркетингу підвищує ефективність та конкурентоспроможність підприємств в умовах глобалізованості ринкового середовища.

Ключові слова: стратегічний маркетинг, стратегічне управління, системно-рефлексивне стратегічне маркетингове управління, системно-рефлексивний маркетинг.

\section{Introduction}

The current stage of development of the world economy, in particular the approach of the phase transition, the essential changes in consumer needs and behavior, the development of the knowledge economy requires new approaches in making managerial decisions, and should take into account the prospects for the formation of new markets and market niches. The intensity of competition is increasing both on the global market and on its local sectors, which leads to the need to develop marketing competencies of enterprises. Low rates of economic growth and the urgent need for drastic changes in the economy of Ukraine, which, in particular, provides for the management and technological modernization of enterprises, the development of postindustrial sectors of the economy, the development of small and medium-sized businesses requires increasing the marketing competencies of managers and the introduction of proactive strategic approaches in entrepreneurship. Under such conditions, the formation of a strategic competitive position of enterprises becomes possible, in particular, by introducing a system-reflexive strategic marketing management to accelerate the diffusion of managerial and market innovations, aligning interests in partnerships, and applying proactive market management.

\section{The object of research and its technological audit}

The object of research is the strategic marketing activity of enterprises in the conditions of transformation of the market environment in Ukraine. The subject of research is the theoretical and methodological foundations of system-reflexive strategic marketing management in the activities of Ukrainian enterprises and the formation of marketing strategies.

\section{The aim and objectives of research}

The aim of research is development of a methodology and practical application of system-reflexive strategic marketing management (SRSMM). According to the aim of the research, the following tasks are set:

1. Studying of the genesis and conceptual foundations of the formation of strategic marketing management system at enterprises.

2. Formation of the SRSMM system, which integrates strategic marketing solutions into a single system of marketing strategies focused on strengthening competitive positions in the global market environment.

3. Definition of the mechanism for formation of marketing strategies in SRSMM at the enterprise. 


\section{Research of existing solutions of the problem}

The absence of the concept of strategic marketing management in new conditions, which developed existing views and responded to world economic processes, slows down the development of enterprise management systems and constitutes a scientific problem. It is necessary to understand and implement system-reflexive strategic marketing management that is a modern concept of strategic marketing, systemic reflection of business entities, formation of decision-making systems in conditions of uncertainty, transformations and globalization in both scientific and practical aspects. In modern economic literature, there are many works devoted to functional marketing, but not enough fundamental theoretical and methodological developments that would consider strategic marketing as a paradigm of strategic management of entrepreneurial activity, the basic principle of strengthening market positions of subjects in the global market environment.

The fundamental problems of strategic management development are covered in the works of many foreign scientists, in particular [1-8]. In the classical paper [1] for the first time the concepts of strategic management and marketing are systematically integrated into the development of another classical work [2], which fixed the transformation of strategic planning into strategic management. In work [4] it is noted that innovations become decisive in competitive struggle, and in work [8] approaches to achievement of competitive advantage are systematized. In work [7], various models of strategic management are analyzed, and these developments form the basis for SRSMM analysis.

Strategic management based on marketing, can be defined as strategic marketing management, disclosed in [9-15]. In $[9,10]$, the role of marketing in the world is considered, it is changing rapidly. These works largely determined the marketing discourse of this decade. In work [12] management is already considered inseparably from market management. Work [14] defines the role of marketing strategies in the management of the company in the Ukrainian market, and [13] - expands the object of marketing management to the international market. In work [15] the methodology of strategic management of marketing activity and interaction of elements of market networks are systematized.

The issues of reflexive management in the economy and, in particular, in management activities, are considered in $[16,17]$. The subject of these works is applied aspects of managing the economy, the enterprise and individual processes, including sales processes.

However, the above work does not represent the systematic nature of the reflexive activity of the subject of marketing strategy.

\section{Methods of research}

During 2007-2016, we conducted two studies of marketing activities in Ukrainian business. The first study of the «Business Management System in Ukraine» included an expert survey of the management of Ukrainian enterprises [18]. The sample consisted of 414 small, medium and large enterprises of various organizational forms, forms of ownership and commodity markets; the period of re- search included the first wave (2007-2008), the second wave (2009-2014) and the third wave (2015-2016) of selective observation. The second study of the «Model of Strategic Management of Entrepreneurship and Marketing Activity» provided for an in-depth study of 59 enterprises, which included monitoring the technologies of conducting market activities and making managerial decisions for up to 2-4 years (continuously in the period from 2007 to 2016), performance analysis of indicators of the success of brands of enterprises, expert surveys of the top and functional leadership and external experts (including business partners), survey of clients, modeling, empirical research (including through the introduction of systemreflexive strategic marketing management).

\section{Research results}

It is determined that the traditional view on marketing management and the formation of marketing strategies significantly limits how the ability of relevant (functional marketing) managers to influence the formation of corporate and business strategies, and actually gives marketing the role of a «participant» rather than a «moderator» of strategic management. Even attempts to show the importance of the role of the marketing department are not enough for marketing to become the guiding ideology in strategic management, the very existence of «marketing units» indicates that marketing is only a subsystem in the management system of many enterprises.

The proposed combination of strategic management and strategic marketing is based on the provisions of strategic management:

- consideration of interests of stakeholders;

- orientation to collective knowledge, competence and resources of the enterprise;

- formation of strategies aimed at the realization of long-term interests;

- dependence on the management style of the manager; - perception of the market environment as a set of managed and unmanaged factors;

- the object of management is business activity (the activity of an enterprise on the market, including the market itself).

System-reflexive strategic marketing management assumes that marketing becomes the primary ideology of business management, that is, the formation of an integrated marketing strategy becomes the responsibility of the top management of the enterprise. In fact, marketing does not simply dissolve in the management system, but creates and cement it. All business units of the company become marketing, that is, those whose activities are based on the principle of marketing, in addition, formed and functional units responsible for the elements of functional marketing (in particular, market analytics, commodity management, branded, category policies, management of integrated marketing communications, sales, etc.).

The integrated marketing strategy assumes acceptance of the administrative decisions concerning the coordination of interests of internal stakeholders; coordination of the collective interest of internal stakeholders, which is formalized for the purposes of the enterprise, and the interests of external stakeholders (in particular, the commodity-market strategy); functional marketing strategies (purchasing, sales, promotion, pricing strategies, etc.). An integrated marketing 
strategy actually determines the corporate strategy and strategies of business units.

Increasing the effectiveness of marketing activities of Ukrainian enterprises is directly related to improvement of the procedures for making managerial decisions at enterprises. The effectiveness of entrepreneurial activity is largely determined by the role that marketing plays in entrepreneurial activities. Our research shows a high degree of association between the coherence degree of the marketing strategy with the company's strategy and the indicator of the success of entrepreneurial activity.

Integrated marketing strategy in system-reflexive strategic marketing management is the central link in the formation of corporate strategy and strategies of units and Strategic Business Units. Marketing strategy is a generalized concept that assumes the adoption of various decisions on market and commodity policies, therefore we are talking about an integrated marketing strategy in which all decisions are combined and correspond to a system of strategic goals and a strategic vision.

To date, the marketing strategy is the basis of the business strategy in only $7 \%$ of investigated enterprises. At the same time, $52 \%$ of enterprises do not have a marketing strategy or are not coordinated with the business strategy that is shown in Fig. 1.

The modern spread of strategic marketing concept, due to the increased differentiation of consumer interests, on the one hand, and the corresponding acceleration of improving the capabilities of commodity producers, on the other, determines the priority direction of the strategic development of most enterprises. It is the marketing direction of entrepreneurial activity (in particular, its client-oriented approach) that allows the most successful formation of competitive advantages in modern market conditions. The concept of marketing shows that an enterprise that will adjust itself to a more effective satisfaction of the existing and potential interests of consumers in comparison with competitors substantially increases the probability of achieving its goals.
The introduction of strategic marketing as an approach to enterprise management requires the formation of a system for making and executing management decisions, based on the principles of aligning the interests of stakeholders, but some researchers proceed from other provisions. Existing models are rather formal and do not reflect the essence of strategic marketing. In system-reflexive strategic marketing management, an integrated system of strategic marketing acquires new features. First of all, this concerns the allocation of subject subsystems for making managerial decisions, namely, the formation of Reflexive Marketing Manager (RMM) interests (which is regarded as the actual manager of the enterprise) and the coordination of the interests of internal stakeholders (Fig. 2).

The proposed integrated system for the system-reflexive paradigm of strategic marketing is based on a combination of three levels of alignment of interests. The first level provides for objectifying the interest of the head of the management object, as well as its actualization in relation to the interests of the manager. The result is the prevailing view of the management object and the direction of its transformation (the object of interest) associated in the mind of the manager with the expected benefits of the transformation. The interest of the manager is formalized in the Big Hairy Audacious Goals, which is an element of agreement at the second level.

The second level is the coordination of the interests of internal stakeholders, which includes the reflexive marketing manager (or the actual manager of the management object). RMM (or the actual manager of the enterprise) organizes and manages the process of harmonizing the interests of internal stakeholders. The result of such coordination becomes the vision of the control object.

The third level of coordination provides for the formation of a strategy for coordinating the vision of the enterprise and the interests of external stakeholders. Depending on the object of management, the result of the agreement can be the commodity-market strategy of the enterprise, the strategic positioning of the brand, the strategy of changing the culture of consumption of the product.

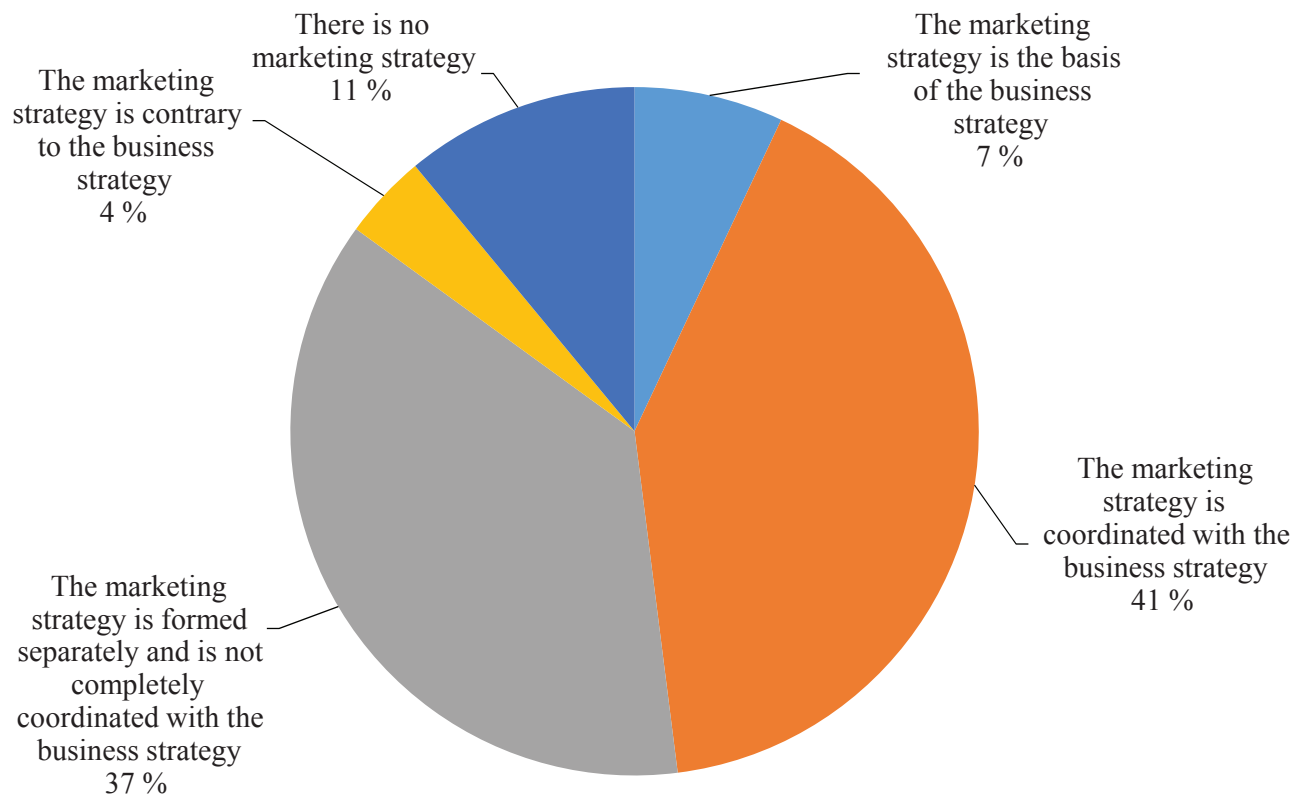

Fig. 1. Coordination of the marketing strategy and the business strategy Source: author's own research 


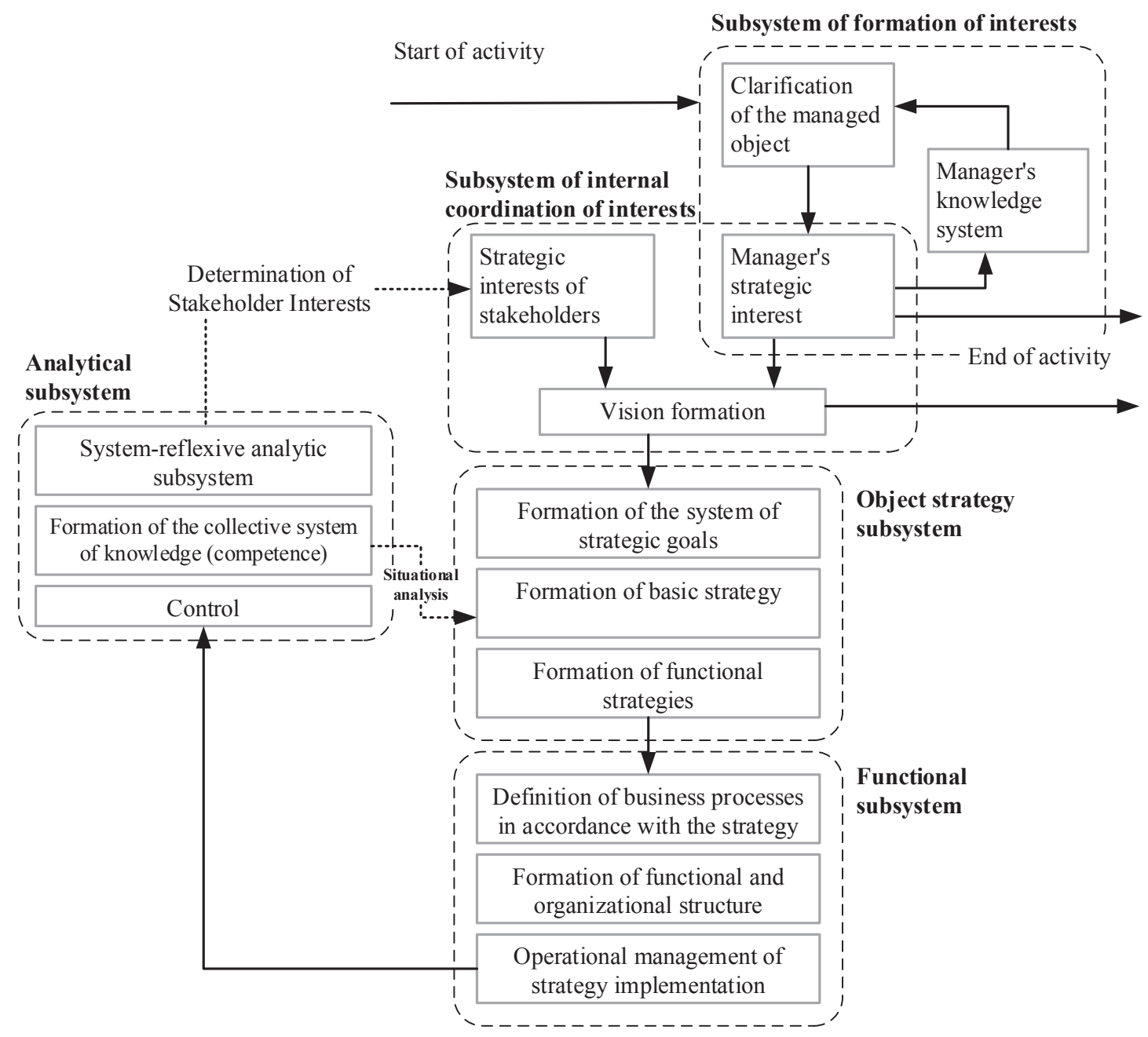

Fig. 2. Integrated system of system-reflexive marketing Source: author's own developments

Returning to the integrated system of strategic marketing, let's note that the first two levels of alignment are reflected in the subsystem of formation of RMM interest and subsystem of internal coordination of interests. The strategy formation subsystem assumes a mutual refinement of the system of strategic goals, basic and functional strategies. It is important that the functional subsystem is formed in the context of strategic decisions. The analytical subsystem is at the same time an auxiliary one (informational support for the adoption of strategic decisions, the formation of a system of knowledge and clarification of interests) and a control system through the feedback mechanism. It is control that initiates repeated decision-making cycles due to a change in the interests of stakeholders or the ineffectiveness of reconciling existing interests (due to mistakes in the strategy or means of market exchange).

A key principle of the integrated system of strategic marketing (based on system-reflexive marketing) is the departure from the project management form to the program form. The essence of the difference lies in the fact that the interests, goals, strategies, strategic plan is not a definite and static planning horizon. The management activity itself presupposes constant clarification of interests, goals, strategies and plans. In practice, this requires considering the target setting and realizing the goals as parallel, rather than sequential, processes are interrelated.
To implement the program form of system-reflexive strategic marketing management, a three-cycle model is proposed. A programmatic approach to strategic management changes the notion of strategy as a long-term «large-block» plan. The strategy is considered as a set of principles. However, a long-term plan can also be a form of representation of principles, a form of organizing tactical thinking, if it does not contain concrete planned actions or acts of activity, but is a list of stages indicating how these steps should be planned (or projected). Determination of principles, methods of planning and designing of details allows to consider the plan as strategic.

For the marketing manager of the 3-5-th level of reflection, marketing is a functional direction in the management of an enterprise. According to marketing as a function, it can be included in the formation of the enterprise vision, the basic strategy and the system of strategic goals, but more often it receives the above-mentioned strategic decisions as input for the further formation of a functional marketing strategy. In the future, let's distinguish between strategic and operational marketing. The scope of strategic marketing tasks is a systematic and continuous analysis of the needs of key consumer groups, as well as development of concepts of effective products, allow the company to serve selected customer groups better than competitors, and thus provide the manufacturer with 
a sustainable competitive advantage. The role of operational marketing is organization of sales and communication to inform potential buyers and demonstrate the distinctive qualities of the product to reduce the cost of finding customers.

A reflexive marketing manager of 6-7-th level of reflection expands its own management object in business or the market as a whole. According to the principle of actual ownership RMM «appropriates» the management object (that is, it becomes the actual manager), and according to the marketing principle RMM coordinates its interests with the interests of other stakeholders of the management object. A different typology of stakeholders leads to three levels of alignment of interests that exist and are realized simultaneously, while a solution of one level determines the decisions of the other. In practice, this requires a cyclic programmatic approach to management.

The basic ideas of a cyclic management model are:

- cyclic nature of the clarification of the management object and the interests of the head of the facility;

- reconciliation of interests in the event of a change

in the interests of stakeholders;

- formation of a sequence of actions as a system with feedback, that is, there should be a monitoring system with the ability to promptly adjust the actions while monitoring the deviations of the result from the expected indicator;

- cycles of different levels are cycles of «different speeds», that is, fewer cycles can last from a week to several months, medium - from a quarter to several years, large - from 1 to 5-10 years;

- «real time» management, that is, the restart of the corresponding management cycle when the input conditions change;

- cycles reflect the boundaries for possible decisions taken at the appropriate levels of leadership.

Each of the cycles may end:

- with complete fulfillment of assigned tasks;

- if it is impossible to fulfill them (the need for higher-

level decision-making);

- if the external conditions or interests of the head (stakeholders) of the relevant cycle change;

- directive when changing tasks on a higher level cycle. One of the advantages of the cyclic approach is the possibility of introducing a greater formalization in the activities of the enterprise and the system of making managerial decisions.

Although marketing is primarily a creative discipline, in practice it requires innovation and non-standard approaches, but in Ukraine it is hypertrophied to an intuitive (entrepreneurial) approach and the prevalence of creative decisions over analysis, research and strategic planning, so a great marketing formalization makes it possible to increase the effectiveness of marketing activities. And especially this will concern strategic prospects. In the current period of marketing formation in Ukraine, more attention is paid to tactical effectiveness, often leads to medium- and longterm failures or inefficient market activities. The model of three cycles of marketing activities, developed to build an integrated SRM system, was successfully tested at several large and medium-sized Ukrainian enterprises. The basis of the three cycle model is the principle of «different speeds» and different levels of marketing decisions. The key idea of the three-cycle model is the distribution of marketing decisions at three levels relative to their impact on the activities of the enterprise and the level of positions of those who make these decisions.

The solution of the first cycle is the key decisions of the activity and the future of the enterprise, the solution of the corporate strategy. These decisions are made by business managers (key internal stakeholders). The task of marketing is identification of promising core markets, strategic analysis and moderation of the alignment of the interests of internal stakeholders. Strategic marketing decisions taken by the enterprise manager and management of marketing services are related to the second level. Functional units are responsible for development and implementation of tactical solutions at the third cycle level. These decisions are approved by the management of the marketing department, and are carried out by the marketing and sales departments.

Each level of decision-making in the three-cycle model corresponds to the level of coordination of interests. The big cycle provides for the coordination of interests of key stakeholders of the enterprise. The result of the coordination of interests is the formation of the vision of the enterprise. The middle cycle involves reconciliation of both internal interests (functional managers) and formation of a strategy that provides for the coordination of interests with external stakeholders (in particular, consumers, suppliers, partners, contact audiences, etc.). In the small cycle, there is a direct exchange as a mechanism for realizing the interests of stakeholders.

Big business cycle of an enterprise consists of three stages, as shown in Fig. 3.

1. Fundamental market research (global market strategic analysis), identification of the strategic interests of stakeholders, formation of a view of the basic markets and the enterprise as management objects.

2. Definition of the vision, the system of strategic goals and corporate strategy.

3. Formation and implementation of product-market strategy, monitoring and correction.

At the second stage of the big cycle, strategic decisions are made, on which the strategic program and strategic plans are subsequently built. In particular, these are decisions concerning the choice of the underlying market, the formation of a vision and the development of a system of strategic objectives. The third stage is the average cycle of activities (adoption and implementation of decisions within the framework of the basic market and the system of strategic objectives of the enterprise).

The middle cycle corresponds to the business strategy and consists of the following stages.

1. Applied market research (determination of interests of external stakeholders, demand, etc.).

2. Development of a market strategy (segmentation and coverage of the market, basic competitive strategy and strategy of competitive behavior, growth strategy), product strategy (product concept formulation, assortment policy, brand policy, etc.) and positioning strategy consolidating commodity and market strategy. At this stage, also testing the design of the goods, the development of the product itself and its testing.

3. Development of functional strategies, which include financial, organizational and personnel strategies, strategies for promotion, marketing, production, procurement, etc. The price strategy is determined. 
4. Implementation of the strategy - tactical and operational plans and actions. At this stage, resources are attracted, supply chains and sales are being established, the basic price of the goods and the system of discounts, margins and price insurance are formed; the system of trade-marketing is formed and implemented; promotions are held on sales promotion. Also at this stage, the operative actions of relationship marketing are realized.

5. Monitoring and correction at the level of strategy or tactical actions.

The small cycle begins when a program (or plan) of activity is developed, is the result of the middle cycle. The end of a small cycle, that is, a return to the middle cycle, occurs when monitoring indicates inefficiency of tactical actions that require a review of the strategy (viewing production technologies, changing the production or trading chain, improving or strengthening the brand, developing a new sales promotion program, modifications to the goods, etc.). Also, a small cycle can be terminated if the current plan is fully implemented or the plan is adjusted «rom above».

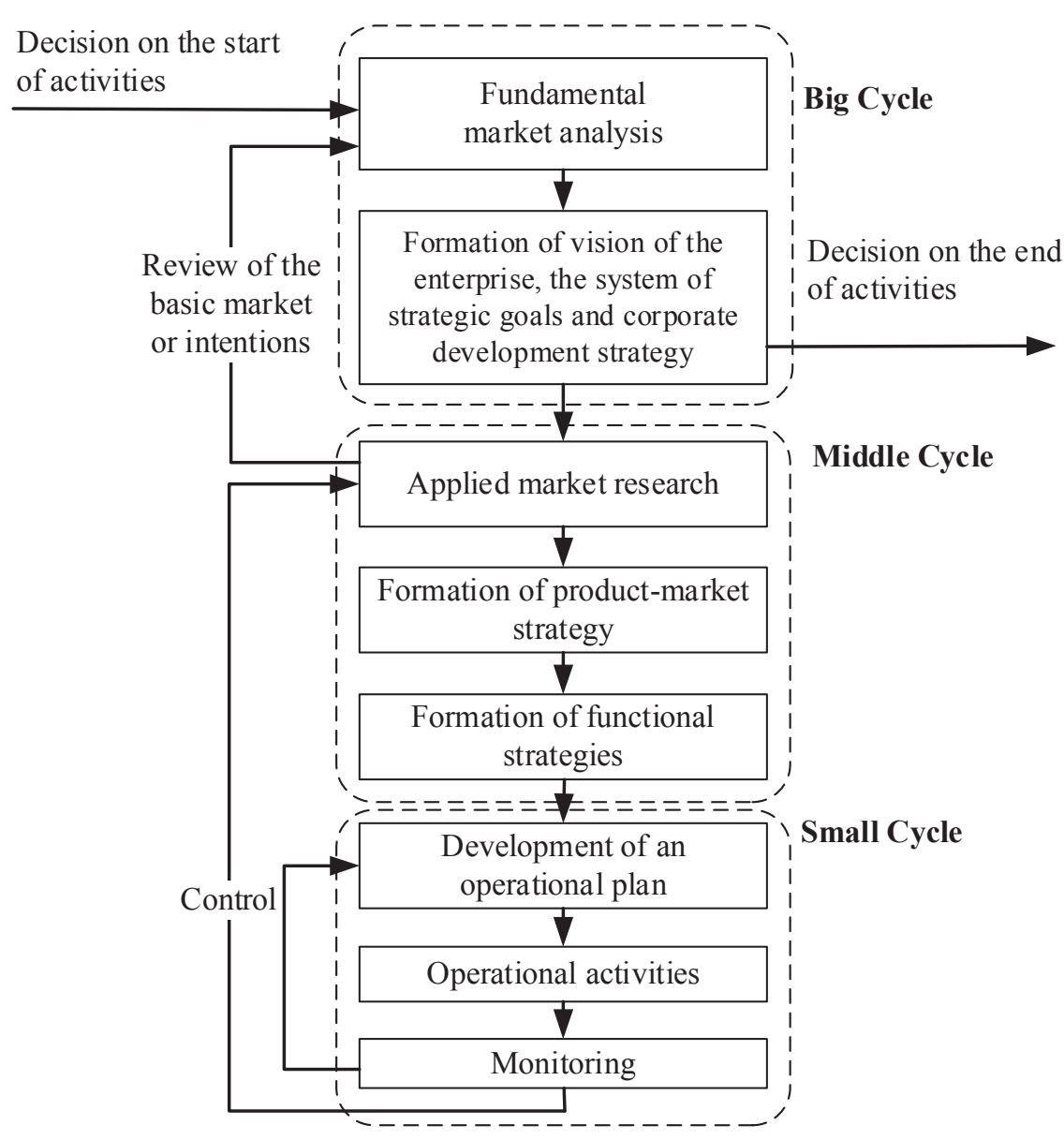

Fig. 3. Model of formation of marketing strategy of the enterprise on the basis of system-reflexive marketing

Source: author's own developments

- other.

- tactics of pricing (formation of systems of discounts and margins, insurance of prices, accounting for the psychological factor);

- trade marketing (merchandising, etc.);

- relationship marketing;

The three-cycle management model in the practical application of the integrated SRM system provides an opportunity to coordinate the changing interests of stakeholders in real time. Unlike the rigid forms of strategic planning, the program approach in the three-cycle management model allows more fully to take into account stakeholder interests in the formation and implementation of managerial decisions, strategies and operational actions. An important result is the formation and expansion of the system of collective knowledge in entrepreneurial activity and the knowledge system of the manager. Flexibility of management in the three-cycle model allows RMM of the 6 -th level to adapt the enterprise to the changes in the environment promptly, and RMM of the 7-th level to correct the development directions of the managed market.

The globalization of the market environment and, in particular, the globalization of stakeholders, leads to an increase in the factors of influence on the adoption of managerial decisions. The big cycle of business management is aimed at forming and coordinating the interests of internal (in particular, global) stakeholders. The middle cycle consists in studying the interests of external (local and global) stakeholders, determining the mechanism for the formation, coordination and implementation of interests. In the end, the small cycle consists in the introduction of a certain mechanism, the realization of interests in the process of market exchange. The synergistic basic and functional strategies of the company, centered on an integrated marketing strategy, will be coordinated as a success factor in the formation and implementation of the mechanism for the formation, coordination and implementation of stakeholder interests.

The strategic process must always be controlled, conscious and uniquely proactive. Considering the fact that the three-cycle management model in the SRM is developed on a programmatic principle, the processes of formation and implementation of the strategy are not sequential but parallel. The strategy, like entrepreneurial activity in general and the manager's knowledge system, are systems that are selfimproving through the cyclic nature of actions in system-reflexive activity.

A small cycle in the context of functional marketing activities, namely the implementation of marketing strategy at the level of tactical events, includes:

- implementation of promotion and marketing programs;
The introduction of system-reflexive strategic marketing management of enterprises in Ukraine provides the following.

1. Introduction of a three-cycle program management form in enterprises. 
2. Stimulating a proactive strategic approach to the market environment.

3. Revision of the definition of the basic market of the enterprise and strategic goals and bringing them in line with the interests of the stakeholders.

4. Expansion of the management object to the market as a whole.

5. Implementation of the formation of corporate strategy and strategy of business units.

6. Implementation of the strategic control system.

\section{SWOT analysis of research results}

Strengths of the system-reflexive approach in formation of marketing strategies are a pro-active approach, allows to manage the development of market interaction; subjective position of the manager, which allows to realize his interests by implementing an appropriate marketing strategy; increase business competitiveness and accelerate the diffusion of innovation.

Weakness can be attributed to the complexity of SRSMM system and the need to allocate functional positions for individual subsystems.

Opportunity is the development of system-reflexive management as an approach not only for marketing activities.

Threats to the successful implementation of SRSMM can be considered insufficient development in the management environment of reflexive and critical thinking.

\section{Conclusions}

As research results, the following results are determined.

1. System-reflexive marketing represents a new paradigm of marketing and strategic management and generalizes the stages of their evolutionary development. The use of system-reflexive marketing in the activities of the enterprise makes it possible to constructively resolve internal and external conflicts, to form a strategic vision and corporate strategy, to help the subjects of management determine the management object and their own interests in relation to it; increases the efficiency of activities. In turn, this contributes to the development of entrepreneurship in Ukraine and to increase the competitiveness of domestic enterprises in a globalized market environment.

2. The principle of the integrated SRSMM system is the departure from the project management form to the program one, in which the interests, goals, strategies, strategic plan is not definite and static in the planning horizon, and the management activity itself presupposes constant clarification of interests, goals, strategies and plans.

3. For implementation of the program form of systemreflexive strategic marketing management, a three-cycle management model is proposed, as a set of methods, forms and tools for coordinating stakeholder interests at three levels: (1) objectifying the manager's interest in the management object, as well as actualizing interest in relation to other interests of the manager, the result is the prevailing view of the management object and the direction of its transformation (objectified interest), related for manager with the expected benefits from the transformation; (2) aligning the interests of internal stakeholders, including the reflexive marketing manager; (3) formation of a strategy in the process of coordinating the interests of external stakeholders, which, unlike existing approaches, allowed to reflect the subject approach in the formation of entrepreneurial strategies and to develop a mechanism for managing the alignment of stakeholder interests in the process of forming a marketing strategy.

\section{References}

1. Aaker, D. A. Strategic Market Management [Text] / D. A. Aaker. Ed. 4. - New York: John Wiley \& Sons Inc., 1995. - 379 p.

2. Ansoff, H. I. Implanting Strategic Management [Text] / H. I. Ansoff. - Englewood Cliffs, NJ: Prentice-Hall, 1984. - 544 p.

3. David, F. R. Strategic Management: Concepts and Cases [Text] / F. R. David. - Ed. 13. - New Jersey: Prentice Hall, 2011 - 694 p.

4. Drucker, P. F. Innovation and entrepreneurship. Practice and principles [Text] / P. F. Drucker. - New York: Harper and Row, $1985 .-258 \mathrm{p}$.

5. Grunig, R. Process-based Strategic Planning [Text] / R. Grunig, R. Kuhn. - Ed. 6. - Berlin, Heidelberg: Springer-Verlag, 2011. 358 p. doi:10.1007/978-3-642-16715-7

6. Hamel, G. Competing for the future [Text] / G. Hamel, C. K. Prahalad. - Boston: Harvard Business School Press, 1994. - 358 p.

7. Mintzberg, H. Strategy Safari: The Complete Guide Through the Wilds of Strategic Management [Text] / H. Mintzberg, B. Ahlstrand, J. Lampel. - London: Pearson Education, 1998. - 416 p.

8. Porter, M. E. Competitive Advantage: Creating and Sustaining Superior Performance [Text] / M. E. Porter. - New York: Free Press, 1985. - 557 p.

9. Achrol, R. S. Frontiers of the marketing paradigm in the third millennium [Text] / R. S. Achrol, P. Kotler // Journal of the Academy of Marketing Science. - 2011. - Vol. 40, No. 1. P. 35-52. doi:10.1007/s11747-011-0255-4

10. Kotler, P. The Gap between the Vision and Reality of Marketing [Text] / P. Kotler, B. J. Calder, E. C. Malthouse, P. J. Korsten // MIT Sloan Management Review. - 2012. - Vol. 54, No. 1. - P. 12-14.

11. Lancaster, G. Essentials of Marketing Management [Text] G. Lancaster, L. Massingham. - Taylor \& Francis, 2010. - 552 p. doi:10.4324/9780203847206

12. Lambin, J.-J. Market-Driven Management: Strategic and Operational Marketing [Text] / J.-J. Lambin, I. Schuiling. - Palgrave, 2012. $-624 \mathrm{p}$.

13. Bagiev, G. L. Mezhdunarodnyi marketing [Text]: Handbook G. L. Bagiev, N. K. Moiseeva, V. I. Cherenkov. - Ed. 2. St. Petersburg: Piter, 2009. - 688 p.

14. Kudenko, N. V. Marketynhovi stratehii firmy [Text]: Monograph N. V. Kudenko. - Kyiv: KNEU, 2002. - 245 p.

15. Raiko, D. V. Stratehichne upravlinnia rozvytkom marketynhovoi diialnosti: metodolohiia ta orhanizatsiia [Text]: Monograph / D. V. Raiko. - Kharkiv: VD «Inzhek», 2008. - 632 p.

16. Lepa, R. N. Refleksivnye protsessy v ekonomike: kontseptsii, modeli, prikladnye aspekty [Text]: Monograph / R. N. Lepa, S. N. Shkarlet et al.; ed. by R. N. Lepa. - Donetsk: Noulidzh, 2011. - 408 p.

17. Lepa, R. N. Modeli refleksivnogo upravleniia v ekonomike [Text] Monograph / R. N. Lepa. - Donetsk: Institute of Industrial Economics, National Academy of Sciences of Ukraine, 2012. - 380 p.

18. Dligach, A. A. Sistemno-refleksivnyi marketing [Text]: Monograph / A. A. Dligach. - Kyiv: Alerta, 2014. - 400 p.

\section{ФОРМИРОВАНИЕ МАРКЕТИНГОВЫХ СТРАТЕГИЙ В СИСТЕМНО- РЕФЛЕКСИВНОМ МАРКЕТИНГЕ}

Предложены интегрированная система системно-рефлексивного маркетинга, основанная на программной форме управления, и трициклические модели формирования стратегии, как совокупность методов, форм и инструментов согласования интересов стейкхолдеров на трех уровнях: опредмечивания интереса управляющего по отношению к объекту управления; согласование интересов внутренних стейкхолдеров; формирование стратегии в процессе согласования интересов внешних стейкхолдеров. Применение системно-рефлексивного маркетинга повышает эффективность и конкурентоспособность предприятий в условиях глобализированности рыночной среды.

ключевъе слова: стратегический маркетинг, стратегическое управление, системно-рефлексивное стратегическое маркетинговое управление, системно-рефлексивный маркетинг.

Dligach Andrii, Doctor of Economic Sciences, Associate Professor, De partment of International Economics and Marketing, Taras Shevchenko National University of Kyiv, Ukraine, e-mail: ad@advanter.ua, ORCID: http://orcid.org/0000-0001-6818-9290 